\title{
Changing Contract Lenses: Unexpected Supervening Events in English, New Zealand, U.S., Japanese, and International Sales Law and Practice
}

Luke Nottage

University of Sydney

Follow this and additional works at: https://www.repository.law.indiana.edu/ijgls

Part of the Contracts Commons, Government Contracts Commons, and the International Law Commons

\section{Recommended Citation}

Nottage, Luke (2007) "Changing Contract Lenses: Unexpected Supervening Events in English, New Zealand, U.S., Japanese, and International Sales Law and Practice," Indiana Journal of Global Legal Studies: Vol. 14 : Iss. 2 , Article 9.

Available at: https://www.repository.law.indiana.edu/ijgls/vol14/iss2/9

This Symposium is brought to you for free and open access by the Law School Journals at Digital Repository @ Maurer Law. It has been accepted for inclusion in Indiana Journal of Global Legal Studies by an authorized editor of Digital Repository @ Maurer Law. For more information, please contact rvaughan@indiana.edu.

\section{$\Psi$}

JEROME HALL LAW LIBRARY

INDIANA UNIVERSITY

Maurer School of Law
Blooming ton 


\title{
Changing Contract Lenses: Unexpected Supervening Events in English, New Zealand, U.S., Japanese, and International Sales Law and Practice
}

\author{
Luke Nottage*
}

Abstract

This article compares differences in the reasoning underlying contractual relationships between English and New Zealand law and U.S. and Japanese law. It then builds upon an existing framework by adding the notion of didactic formality to identify another important contrast between the laws of these countries. It also discusses how CISG and UPICC fit in to this spectrum. The article concludes by questioning "strong convergence" theory in commercial law worldwide.

\section{Form and Substance in Comparative Contract Law}

Twenty years ago, two renowned scholars from different sides of the Atlantic wrote a convincing analysis of an important divide within the so-called common law world. Patrick Atiyah and Robert Summers argued that compared to English law, U.S. law was much more open to "substantive reasoning"-_moral, economic, political, institutional or other consideration[s]" - and had developed an array of legal institutions to support that vision of law. ${ }^{1}$ The framework they developed to prove this thesis can be extended to reveal how New Zealand law remains quite firmly within the English law tradition. By contrast, Japanese law favors more substantive reasoning, thus revealing important similarities to U.S.

- University of Sydney Faculty of Law; Co-Director, Australian Network for Japanese Law; Program Director (Comparative Associate Professor and Global Law), Sydney Centre for International Law; Advisory Board member, C.L.P.E. (Comparative Research in Law and Political Economy). Particular thanks to Anthony Angelo and Joel Rheuben, as well as Peer Zumbansen and participants in the second C.L.P.E. conference, Toronto, November 9-10, 2006.

1. P.S. Atiyah \& Robert S. Summers, Form and Substance in Anglo-American Law: A Comparative Study of Legal Reasoning, Legal Theory, and Legal Institutions 1 (1987). 
law rather than the large differences emphasized until recent years. ${ }^{2}$ The formsubstance distinction also helps in highlighting tensions within both the procedural lex mercatoria (primarily, transnational commercial arbitration) and the substantive lex mercatoria (including the patchy "reception" of the 1980 United Nations Convention on Contracts for the International Sale of Goods (CISG)). ${ }^{3}$

Unsurprisingly, given their reputations as both legal theorists and contract law scholars, the framework proposed by Atiyah and Summers proves particularly useful in comparing contract law systems. ${ }^{4}$ One example comes from the field of contractual unfairness. One dimension of more formal reasoning that they identify is "authoritativeness formality," which always arises because "rules or other phenomena (such as contracts or verdicts) which generate reasons must be recognized as legally authoritative." However, this type of formality may involve low or high "validity formality," depending on whether legal standards by which the validity of legal phenomena is determined are content-oriented (inviting inquiry into substance) as opposed to source-oriented (requiring inquiry into the mode of origin to

2. Luke Nottage, The Japanisation of American Law? Substantive Similarities, Compared to Formal Anglo-New Zealand Law, 1 (Sydney Law Sch. Research Paper, forthcoming), draft available at http://www.law.usyd.edu.au/anjel/documents/ResearchPublications/JapanisationOfAmericanLaw.pdf. [hereinafter Nottage, Japanisation of American Law?]; see also Daniel Foote, SaIBan to Shaka [ The Judiciary in Society] (NTT Shuppan 2006) (Japan) (arguing that the judiciary in Japan has also long been involved in policy making, albeit not to the same extent as in the United States). But see R. Daniel Kelemen \& Eric C. Sibbitt, The Americanization of Japanese Law, 23 U. PA. J. INT'L Econ. L. 269 (2002) (suggesting that the Japanese legal system has been quite different, but is recently "Americanizing" due to economic liberalization, political fragmentation and the growth of legal services markets).

3. For a discussion of these tensions, see, for example Luke Nottage, Practical and Theoretical Implications of the Lex Mercatoria for Japan: CENTRAL's Empirical Study on the Use of Transnational Law, 4 Vindobona J. In't' Com. L. \& Arb. 132 (2000); Luke Nottage, The Procedural Lex Mercatoria: The Past, Present and Future of International Commercial Arbitration (Kobe University Center for Legal Dynamics of Advanced Market Societies Discussion Paper No. 03-E1, 2003), available at www.cdams.kobe-u.ac.jp/archive/dp03-1.pdf. For a discussion on the application of the CISG, see Luke Nottage, Who's Afraid of the Vienna Sales Convention (CISG)? A New Zealander's View from Australia and Japan, 36 VICtor IA U. Wellington L. Rev. 815, 828 (2005) [hereinafter Nottage, Who's Afraid of the CISG?].

4. For more recent writing emphasizing the differences between English and U.S. contract law generally, see William C. Whitford, A Comparison of British and American Attitudes Towards the Exercise of Judicial Discretion in Contract Law, in Implicit Dimensions of Contract: Discrete, Relational and Network Contracts 187 (David Campbell et al. eds., 2003). On the distinctive approaches to the private law of restitution, see Chaim Saiman, "Restitution in America: Why the U.S. Refuses to Join the Global Restitution Party" (April 2007), Villanova Law/Public Policy Research Paper No. 2007-9, available at http://ssrn.com/abstract $=980254$.

5. Atiyah \& Summers, supra note 1 , at 12. 
determine validity). Japanese and U.S. law apply significantly broader content-oriented standards of good faith and/or unconscionability. English and New Zealand law prefer more source-oriented rules focused on the party's agreement, especially the negotiation process (procedural justice) rather than the resultant contract terms (substantive justice). ${ }^{6}$ Overall, this is also consistent with a classical or neoclassical model of contract law, attempting to define the scope of contractual obligations by reference to what was agreed by the parties, rather than by examining the multifaceted "contextual dimension" to contractual relationships."

Part II of this article argues that English and, perhaps especially, New Zealand law likewise exhibit distinctly greater authoritative formality in a core doctrine developed to address supervening impediments to contractual performance in the event of extreme changes of circumstances, namely the law of frustration (discussed in subpart A). U.S. and especially Japanese law prefer more substantive reasoning (discussed in subparts $B$ and $C$ ). Again, the contrast reveals the deeprootedness of the classical or at least neoclassical model in Anglo-New Zealand law, not giving sufficient due as well to the "time dimension" in contractual rela-

6. Luke R. Nottage, Form and Substance in U.S., English, New Zealand and Japanese Law: A Framework for Better Comparisons of Developments in the Law of Unfair Contracts, 26 VICTORIA U. Wellington L. Rev. 247, 254 (1996). Other dimensions of formal reasoning suggested by Atiyah and Summers are also useful for contrasting different approaches to the enforceability of agreements reached "subject to contract" or the like, as well as distinct trajectories in contract law theory development. See generally Luke Nottage, Formal Requirements for Contract Formation: AngloNew Zealand Law Versus Japanese, U.S. and International Sales Law, (draft Sydney Law Sch. Research Paper, on file with the editors) [hereinafter Nottage, Formal Requirements]; Luke Nottage, Tracing Trajectories in Contract Law Theory: Form in Anglo-New Zealand Law, Substance in Japan and the US (Sydney Law Sch. Research Paper), available at http://www.law.usyd.edu.au/anjel/ content/anjel_research_pub.html.

7. Ian Macneil famously argued that one feature of both classical and neoclassical contract law is a shared fixation on divorcing contractual relations from their socio-economic context, rendering them more "discrete." Ian R. Macneil, The Many Futures of Contracts, 47 S. CAL. L. Rev. 691 (1974). For sources expanding on this argument, see IAn R. Macneil \& David Campbell, The Relational Theory of Contract: Selected Works of Ian Macneil 188-99 (2001) [hereinafter Macneil \& CAMPBELL] (arguing that the discrete transaction model when modified to represent actual economic life will no longer represent an entirely discrete transaction, but will retain substantial discreteness while becoming relatively realistic); David Campbell, Relational Contract and the Nature of Private Ordering: A Comment on Vincent-Jones, 14 IND. J. Global Legal Stud. 279 (2007) (arguing against the erosion of the individual dimension of contract, and particularly against the claim that it is endorsed by the relational theory of contract, which is distinguished from welfarist law). By contrast, international arbitrators usually strive to recognize the contextual dimension to contractual relationships. Nagla Nassar, Sanctity of Contracts Revisited: A Study in the Theory and Practice of LongTerm International Commercial Transactions 109 (1995). 
tionships. ${ }^{8}$ The article further extends the comparative frame of reference by pointing out that CISG adopts more substantive reasoning, but remains more formal here than the UNIDROIT Principles of International Commercial Contracts (UPICC) (discussed in subpart D), first promulgated in 1994 and now in a 2004 edition.

Part III develops a significant refinement to Atiyah and Summers' model. It outlines some conclusions from preliminary empirical studies comparing attitudes and practices regarding changed circumstances. The gap between contract law "in books" and law "in action" seems greater in English and New Zealand law than that in the United States and Japan, as well as in international sales law compared to actual practice. ${ }^{9}$ Such a significant gap appears to run counter to the thrust of Atiyah and Summers' framework in other respects. To resolve this apparent incongruity, and to bring out a further dimension for comparing legal systems, Part III.B proposes a new variety of formality_- "didactic formality." This refers to the preference or tendency to resolve any gaps by encouraging the law in action to adapt to the law in books (the approach of most English—and especially New Zealand-judges and commentators), rather than vice versa (more common in the United Statesand especially Japan-as well as in international sales law). Arguably, this contrast reinforces the differing attitudes not only with regard to doctrines dealing with supervening changes in circumstances, but also, for example, contractual unfairness, in domestic contract law as well as in UPICC. ${ }^{10}$

8. Macneil additionally stresses the tendency of classical and neoclassical contract law to "presentiate" contractual relations, that is, to bring them into the present. MACNEIL \& CAMPBELL, supra note 7, at 184-87, 800-04. Nagla Nassar refers to this sort of tendency as the "time element" in cross-border contractual relationships. Nassa R, supra note 7, at 115-139.

9. See infra Part III.A. For the full version of the cross-country empirical analysis, see Luke Nottage, Changing Contract Lenses: Renegotiations in English, New Zealand, Japanese, U.S. and International Sales Law and Practice (Nov. 9-10, 2006) (unpublished paper presented at the Second International Comparative Research in Law and Political Economy Conference), http://law. anu.edu.au/anjel/documents/ResearchPublications/NottageCLPE2006paper.pdf. Because the empirical analysis was mainly conducted in the late 1990 s, although comprehensively reported only quite recently, Part II infra mainly compares the "law in books" around that time as well. Id. However, Part II.D infra adds more recent case law on international sales law, as there exists no corresponding sustained empirical analysis of how that "black letter law" compares with international sales "law in action."

10. Although not explored further here, UPICC adds another important provision not found in CISG (and hence left to the otherwise applicable domestic law), allowing for relief from any contract term that unjustifiably gives the other party an "excessive advantage." UNIDROIT PRINCIPles of International Commercial Contracts art. 3.10(1) (2004). This indicates and promotes more substantive reasoning in the "contextual dimension" regarding validity formality (a contentoriented rather than source-oriented standard), as well as underpinning didactic formality. 
Part IV concludes that Atiyah and Summers' framework continues to prove useful in better appreciating considerable convergences (in some structural aspects of both Japanese and U.S. law, for example), yet some persistent divergences (between Japanese and U.S. law, but primarily vis-à-vis the English law tradition). The framework also needs some refinement, but the notion of didactic formality generally supports the dichotomy. It also helps better positioning of, and our understanding of tensions within, transnational contract law regimes like CISG and UPICC. Thus, this article concludes by mainly agreeing with a growing literature skeptical about "strong convergence" theory in commercial law worldwide, as well as in countries like Japan."

\section{II. “Authoritative Formality": Frustration, Impracticability, Changed Circumstances, and Exemption}

\section{A. English and New Zealand Law: Frustration of Contract}

The doctrine of frustration in English law focuses on narrow sources for the validity of the applicable rules, thus heightening authoritative formality. Early cases allowed an excuse from performance obligations by reading into the parties' initial agreement an "implied condition" or term as to the continued existence or future occurrence of a state of affairs (non-destruction of the music hall or the coronation procession, respectively). ${ }^{12}$

Admittedly, as the doctrine of frustration continued to expand in the first half of the twentieth century, this basis came to be criticized as a mere fiction. ${ }^{13}$ The true rationale for excuse was seen by some as lying in the justice or equity of the case $\mathrm{i}^{14}$ - the archetypal content-oriented source of validity. Traces of this view

11. For a review of this literature, see Luke Nottage, Commercial Regulation, in Elgar Encyclopedia of Comparative Law 135 (Jan M. Smits ed., 2006); and Luke Nottage, Nothing New in the (North) East? Interpreting the Rhetoric and Reality of Japanese Corporate Governance (Comparative Research in Law \& Political Econ. Research Paper No. 1/2006, 2006), http://ssrn.com/abstract $=885367$ (with a shorter version forthcoming as chapter 2 of CoRPORATE GovernaNCE IN THE $21^{\text {st }}$ Century: Japan's Gradual Transformation (Nottage et al. eds., 2008)).

12. See, e.g., Taylor v. Caldwell, (1863) 122 Eng. Rep. 309, 312 (K.B.); Krell v. Henry, (1903) 2 K.B. 740,746 (U.K.).

13. See, e.g., Ocean Tramp Tankers Corp. v. V/O Sovfracht (The Eugenia) [1964]2 Q.B. 226, 238 (Lord Denning M.R.).

14. See, e.g., Davis Contractors Ltd. v. Fareham Urban Dist. Council, [1956] A.C. 696, 728 (H.L.) (appeal taken from Eng.) (U.K.); Denny, Mott \& Dickson, Ltd. v. James B. Fraser \& Co., Ltd, [1944] A.C. 265, 275 (H.L.) (appeal taken from Scot.) (U.K.). 
can be detected even quite recently. In National Carriers Ltd. $v$. Panalpina (Northern) Ltd., for instance, Lord Wilberforce proclaimed that "the movement of the law of contract is away from a rigid theory of autonomy towards the discovery-or I do not hesitate to say imposition - by the courts of just solutions, which can be ascribed to reasonable men in the position of the parties." ${ }^{15}$ However, earlier in his speech he reviewed theories underlying the doctrine of frustration, including the theory that it is simply a special exception that justice demands. Nonetheless, Lord Wilberforce concluded that it was unnecessary to single out one theoretical justification for the doctrine of frustration: "they shade into one another and ... a choice between them is a choice between what is most appropriate in the particular contract under consideration." ${ }^{16}$ In deciding to extend in principle the doctrine to leases of land, moreover, his Lordship was of the provisional view that it could be appropriate to refer to an "implied term" (concerning a right of way to the premises, impeded by a council order preventing street access) or to "removal of the foundation of the contract" (namely the use of the premises as a warehouse). ${ }^{17}$ Lord Hailsham L.C., who also reviewed the various bases that had been advanced, preferred the "construction theory," which involves determining the true meaning of the particular contract used. ${ }^{18}$ In The Super Servant Two, Bingham L.J. stated that the "object of the doctrine [of frustration] was to give effect to the demands of justice."19 In the same breath, however, his Lordship referred to the true construction of the contract. ${ }^{20}$ This is also the rationale preferred by at least one leading English commentator today. ${ }^{21}$ It brings English law back toward more source-oriented standards of validity, and therefore more formal reasoning.

Another factor contributing to this turn is the retrenchment in actual application of the doctrine, evident in the latter half of the twentieth century. ${ }^{22}$ This

15. National Carriers Ltd. v. Panalpina (Northern) Ltd., [1981] A.C. 675, 696 (H.L. 1980).

16. Id.

17. Id. at 693 .

18. Id. at 688. Lord Hailsham L.C. then goes on to quote approvingly from Lord Radcliffe's opinion in Davis v. Contractors Ltd., [1956] A.C. 729.

19. Lauritzen A.S. v. Wijsmuller B.V. (The Super Servant Two), (1990) 1 Lloyd's Rep. 1, 8 (U.K.).

20. Id.; accord Denny, Mott \& Dickinson [1944] A.C. at 269.

21. G.H. Treitel, The Law of Contract 860 (9th ed. 1995); see also Andrew J. Morris, Practical Reasoning and Contract as Promise: Extending Contract-Based Criteria to Decide Excuse Cases, 56 CAMBRIDGE L.J. 147, 153 (1997) (stating that the "construction" approach "apparently commands a majority" of support in courts).

22. See Treitel, supra note 21 , at 818-20; see also G.H. Treitel, Frustration and Force MaJEURE 255-65 (1994) (discussing impracticability in English law generally). 
began with some important cases arising out of World War II, took root in cases-particularly on appeal-prompted by closure of the Suez Canal, and is epitomized by the actual results in more recent cases like Palapina and The Super Servant Two. The seemingly growing reluctance to allow discharge by frustration reinforces the argument that commercial impracticability of performance due to extreme changes in market conditions, as opposed to changed circumstances following from some physical impossibility or other circumscribed situations, is not available as an excuse under English law. ${ }^{23}$

Even if such high hurdles can be cleared, a party pleading frustration may not prevail. One difficulty stems from the cases arguing that a contract cannot be frustrated by foreseen or foreseeable events. This can lead to the conclusion that the party seeking application of the doctrine of frustration should have provided against those events. ${ }^{24}$

Another difficulty is the remaining strict view that the doctrine of frustration is not available when the frustration is "self-induced." When The Super Servant Two sank, for instance, the defendant's contract to transport the plaintiff's drilling rig in that or another ship of the defendant was not frustrated. Using the other ship under another contract with a third party was held to be an "election," which amounted to "self-induced" frustration. This rule prevents parties faced with unexpected supervening events affecting a contract's performance from allocating their remaining resources and choosing among several contracts, even on an objectively rational basis. ${ }^{25}$

Overall, such strict attitudes by the English courts seem to be related to the restricted and extreme effects that follow if frustration is found, namely automatic termination at the time of the frustrating event. There is no obligation for the party affected by a drastic change of circumstances to give notice to the other party. The latter can also invoke the doctrine ${ }^{26}$ (even to make a windfall gain) and the courts are not permitted to adjust the parties' contractual obligations instead of terminating them. ${ }^{27}$ Legislation to cover some effects of termination becomes of little practical importance. ${ }^{28}$ In short, the English law of frustration developed out of distinct categories of mainly physical impossibility of performance. The

23. TREITEL, supra note 21 , at $792-97$.

24. Id. at $813-14$.

25. Id. at $817-20$.

26. Id. at $821-22$.

27. See id. at 822.

28. Law Reform (Frustrated Contracts) Act, 1943, $6 \& 7$ Geo. 6, c. 40 (Eng.). For a discussion of one of the few cases in the area of frustrated contracts legislation, see J. W. Carter \& Gregory Tol- 
law was justified originally, and again more recently, by reference to what the parties putatively intend, and its scope of application is very limited-reinforced by the extreme nature of the consequences of finding a contract to be frustrated.

The same can be said for New Zealand law, perhaps all the more so, although there is much less case law and commentary to draw on. A standard textbook rejects the implied condition theory as a basis for the doctrine, preferring Lord Radcliffe's "just solution" approach premised on performance "radically different from that which was undertaken by the contract." ${ }^{2}$ But it concludes immediately:

Nevertheless it would be wrong to say that frustration operates entirely independently of the parties' intentions. For one thing, the "thing which was undertaken by the contract" depends on its true construction. For another, a contract cannot be held frustrated if that would be contrary to the contract's express terms. ${ }^{30}$

This more restrictive approach was reflected quite recently in Power Company Limited v. Gore District Council. ${ }^{31}$ A unanimous Court of Appeal did not allow frustration pleaded on the grounds of commercial impracticability for a contract entered into in 1927 "for all time hereafter" to supply electricity at 1 penny per unit as opposed to the market price of 10.2 cents per unit at the time of the litigation, resulting in the Council paying only $\$ 16,639$ for electricity worth $\$ 204,529$. The Court agreed with Viscount Simon's rejection of the notion that the doctrine of frustration was rooted in what was "just and reasonable," in favor of a "proper interpretation of the contract, having regard to the circumstances" at its formation. ${ }^{32}$ Quoting from Lord Radcliffe in Davis, as approved by Lord Hailsham in Palapina, the court also stated that the test was whether the parties' agreement

should not be treated as applying in a fundamentally different situation. The starting point, however, must still be the contract. The

hurst, Gigs N' Restitution - Frustration and the Statutory Adjustment of Payments and Expenses, 10 J. Cont. L. 264 (1996).

29. Davis Contractors Ltd. v. Fareham Urban Dist. Council [1956] A.C. 696, 729 (H.L.) (appeal taken from Eng.) (U.K.).

30. J. F. Burrows et al., Law of Contract in New Zealand 670 (1997) (emphasis added).

31. Power Co. v. Gore District Council, [1997] I N.Z.L.R. 537 (CA).

32. Id. at 552 (quoting British Movietonews Ltd. v. London \& District Cinemas Ltd. [1952] A.C. $166,181-86)$. 
limited scope of the principle of frustration, as has been pointed out by Viscount Simonds in Tsakiroglou \& Co Ltd v. Noblee Thorl

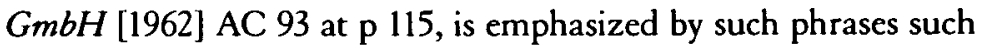
as "fundamentally different" and radically different used in the earlier cases by Viscount Simon, Lord Reid and Lord Radcliffe. ${ }^{33}$

The Court, unimpressed by the power company's argument that the deregulation of public utilities in recent decades had created a very different environment, then focused on the negotiations and wording used in drafting the contract in 1927. It also indicated that government action might be a better solution to this type of problem than the private law doctrine of frustration, a further illustration of the comparative deference of New Zealand judges to the legislature, reinforcing higher authoritative formality generally. ${ }^{34}$ Further showing the formal nature of the reasoning adopted, the Court of Appeal declined to allow this contract for an indefinite term to be terminated on reasonable notice. It stressed that the words used were clear and unqualified, and that there was uncertainty involved in formulating a reasonable notice term. ${ }^{35}$ By contrast, neither factor was sufficient to prevent the majority of the English Court of Appeal from terminating on reasonable notice a 1929 contract imposing an obligation to supply water "at all times hereafter. ${ }^{36}$ Further, because the price fixed in 1929 was 2.9 pence (equivalent) per 1000 gallons whereas the normal rate was 45 pence by 1975, Lord Denning M.R. simply discharged the supplier under the doctrine of frustration. This approach was not expressly disapproved by the other Judges. Further, as one commentator has observed from the perspective of German law, terminating the contract on either basis could be achieved by applying a general duty to act in good faith, ${ }^{37}$ and the same functional equivalence of the doctrines is achievable in this way under Japanese law (discussed in subpart $\mathrm{C}$ ). By refusing to apply either to relieve the supplier under a fixed-term long-term contract in Gore, the New

33. Id. at 553-54; accord National Carriers Ltd. v. Panalpina (Northern), [1981] A.C. 675, 713 (H.L. 1980); Davis Contractors, [1956] A.C. at 729.

34. For a general discussion of authoritative formality, see Nottage, supra note 2, at 7-8.

35. Reticence in the latter respect appears consistent with the unwillingness of the Court of Appeal to uphold "agreements to agree," compared to several leading English and Scottish authorities. See, e.g., D.W. McLauchlan, Rethinking Agreements to Agree, 18 N.Z.U. L. Rev. 77 (1998).

36.Staffordshire Area Health Auth. v. S. Staffordshire Waterworks Co., [1978] 1 W.L.R. 1387, 1398 (Eng.).

37. Norbert Horn, Changes in Circumstances and the Revision of Contracts in Some European Laws and in International Law, in Adaptation and Renecotiation of Contracts in INTERnational Trade and Finance 15, 22-23 (Norbert Horn ed., 1985). 
Zealand Court of Appeal demonstrates a more formal approach than that adopted by the Court of Appeal in Staffordshire. ${ }^{38}$

More generally, in denying frustration, New Zealand courts seem to place considerable weight on the clauses used by the parties in the contract documentation. In Maori Trustee $v$. Prentice, ${ }^{39}$ for example, a sixteen-fold rent increase did not discharge the lessee, primarily because there had been contractual provision for rent review, resulting in the increase. ${ }^{40}$ Extreme changes in circumstances not, or not adequately, covered by a clause can readily be held to have been foreseen or foreseeable, and the risk thereof assumed. Thus, in Hawke's Bay Electric-Power Board v. Thomas Borthwick \& Sons (Australia) Ltd., ${ }^{41}$ the defendants were held to a contract to take electricity from the plaintiff even after the former's works were destroyed by an earthquake. Justice Blair noted that a clause provided for contingencies such as government closure, but not earthquakes, and added that "in a place like New Zealand where earthquakes are not by any means unknown it cannot be said that the fact that there is such a risk is not present in the minds of most business men." ${ }^{24}$ In Des Forges v. Wright, ${ }^{43}$ Justice Elias (now the Chief Justice) held that a contract for the assignment of a distributorship agreement was not frustrated by the subsequent closure of the original manufacturer's plant, resulting in a significant decrease ( 20 to 50 percent by value) of the business generated by the distributorship. She remarked:

the distribution agreement which is assigned by contract specifically permits [the manufacturer] to vary the products for distribution, and sets up its own mechanism by which the parties can deal with each other over variations which affect the distributor. That mechanism envisages alteration of the commission structure or termination "on mutually agreed terms." It is not clear to me why the contractual mechanism was not invoked by the appellants [assignees] after 22 January [following completion of the assignment]. I consider that risk of the type which has eventuated was foreseen and accepted by

38. Compare Power Co. Ltd. v. Gore District Council, [1997] 1 N.Z.L.R 537, 555, with Staffordshire [1978] I W.L.R. 1387.

39. Maori Trustee v. Prentice, [1992] 3 N.Z.L.R. 344.

40. Id. at 354-55.

41. Hawke's Bay Elec. Power Bd. v. Thomas Borthwick \& Sons (Australasia), [1933] N.Z.L.R. 873.

42. Id. at 883 .

43. Des Forges v. Wright, [1996] 2 N.Z.L.R. 758. 
the appellants [assignees] on the basis of the rights available against the distributor and that the loss of the Tenderkist product [from the manufacturer's plant] was not a frustrating event. ${ }^{44}$

Some commentators have submitted that frustration should be allowed despite an event having been foreseen or foreseeable, depending on the inference to be drawn from not having included a clause specifically covering its occurrence. In a particular case, it may be that the parties intended the law of frustration to provide relief. ${ }^{45}$ No such argument has been accepted in recent cases, however. This may not be surprising, in that evidence of such an intention would be rare and difficult to prove to the court. Even then, it focuses the argument only slightly less narrowly on the parties' intentions.

More substantive reasoning, invoking content-oriented standards of validity, seems more likely to succeed in persuading a court to recognize frustration of a contract. ${ }^{46}$ Yet this is precluded by the more formal approach to law generally, and this area of law in particular, in both New Zealand and English law.

\section{B. U.S. Law: Impracticability}

By contrast, U.S. law "candidly recognizes that the judicial function is to determine whether, in the light of exceptional circumstances, justice requires a departure from the general rule that a promisor bears the risk of increased difficulty of performance. ${ }^{.47}$ This follows from the synthesis of the law that emerged in 1952 with the U.C.C. (especially § 2-615) for the sale of goods, reinforced more generally two decades later in the Restatement (Second) of Contracts (especially $\S$ 261). ${ }^{48}$ Commercial impracticability is a well-recognized category. Even Williston, a textbook writer in the classical vein, had recognized that an excuse may be available when performance is "not obtainable except by means and with an expense impracticable in a business sense. ${ }^{49}$ The first Restatement, promulgated in 1931,

44. Id. at 762 .

45. Burrows et AL., supra note 30 , at 680 .

46. Cf. J.F. Burrows, Frustration of Contract, in New Zealand Law Comm'n, Contract Statutes Review 271 app. A at 275 (1993).

47. 2 E. Allan Farnsworth, Farnsworth on Contracts 543 (1990).

48. Restatement (SECOND) of Contracts $§ 261 \mathrm{cmt}$. b (1979) (referring to a "just allocation of risk").

49. 3 Samuel Williston, The Law of Contracts \$1963, at 3336 (1920). 
accordingly laid down that "impossibility means not only strict impossibility but impracticability."

In fact, U.S. courts have infrequently allowed an excuse on the ground of mere increase in cost of performing contractual obligations. But these have included some very well-known instances, often involving large corporations otherwise faced with the possibility of financial ruin, such as the $A L C O A$ case. ${ }^{51}$ Rather similarly, by subsuming distinct categories of physical impossibility (such as continued existence of a thing necessary for performance) under the general rubric of a "basic assumption on which the contract has been made," U.S. law seems to have encouraged courts to sometimes recognize others (such as strikes). That too, therefore, is "in line with the tendency toward liberality in excusing promisors on the occurrence of extraordinary events." ${ }^{\text {" }}$ Post-war reticence in English and New Zealand law therefore stands in marked contrast. ${ }^{53}$

Further, many U.S. cases do hold against the party seeking excuse on the grounds that it assumed a greater obligation than the law imposes; that is, that the party has assumed the risk. Often this is reinforced by the argument that the risk was foreseen or foreseeable. Drawing on other compelling case law and the $R e-$ statement (Second), however, commentators argue powerfully that the latter should only be one factor suggesting that the risk was assumed. ${ }^{54}$ As Comment $\mathrm{c}$ to $\$ 261$ puts it:

If the supervening event was not reasonably foreseeable when the contract was made, the party claiming discharge can hardly be expected to have provided against its occurrence. However, if it was foreseeable, or even foreseen, the opposite conclusion does not necessarily follow. Factors such as the practical difficulty of reaching agreement on the myriad of conceivable terms of a complex agreement may excuse a failure to deal with improbable contingencies. ${ }^{55}$

50. Restatement of Contracts $§ 454$ (1931).

51. Aluminum Co. of Am. v. Essex Group, 499 F.Supp. 53, 72-73 (W.D. Pa. 1980). For commentary on this principle, see Farnsworth, supra note 47, at 547-49; 2 Stewart Macaulay et al., Contracts: Law in Action 728-41 (1995); 1 James J. White \& Robert S. Summers, Uniform Commercial Code 129-30 (4th ed. 1995).

52. Farnsworth, supra note 47, at 550. But see White \& Summers, supra note 51, at 130.

53. See Treitel, supra note 21 , at 242-55.

54. FARNSWORTH, supra note 47 , at 554-56. For analysis based on the Restatement, see White \& SuMMERs, supra note 51 , at $128-29$.

55. Restatement (Second) of Contracts $\$ 261 \mathrm{cmt.} \mathrm{c} \mathrm{(1979).}$ 
This invites a broad-ranging inquiry on this point, with Comment $\mathrm{c}$ mentioning "the extent to which the agreement was standardized, the degree to which the other party supplied the terms, and, in the case of a particular trade or other group, the frequency with which language so allocating the risk is used in that trade or group," person was an intermediary. U.S. courts have expressly adopted similar reasoning, unlike courts in England and, perhaps especially, New Zealand.77

Finally, there is less scope under U.S. law for excuse to be denied on a strict view of what is "self-inducing," because the U.C.C. $(\$ 2-615(\mathrm{~b}))$ simply allows the seller to allocate remaining supplies "in any manner which is fair and reasonable." White and Summers note that this is "descended from more than 100 years of American cases on contract allocation," with the courts generally ratifying the seller's choice of pro rata allocation methods but allowing considerable flexibility. ${ }^{58}$ This approach is reinforced by the generalized duty of good faith in the U.C.C. ( $\$ 1-103)$, paralleled in the Restatement (Second) ( $\$ 205)$.

The greater liberality and more substantive reasoning in the U.S. law with respect to the prerequisites for excuse, overall, is matched by a less strict approach to their effects. On the one hand, impracticability does not automatically terminate the contract. The affected party must give the other reasonable notice before being excused of any remaining obligations to perform and of any obligation to pay damages. This excused failure to perform then affects the other party's duties of performance as if the excused party had broken the contract. Hence, if the failure is material, the other party can first suspend its own performance and terminate the contract after giving an opportunity for the excused party to "cure." Prospective failure of performance due to impracticability has a similar effect. ${ }^{59}$ This conceptual structure tends to keep the contractual relationship alive, meaning that the duty of good faith potentially applies.

Some commentators have even proposed a duty of good faith modification, at

56. Id. (internal citations omitted).

57. Compare Opera Co. of Boston v. Wolf Trap Found. for the Performing Arts, 817 F.2d. 1094, 1101 (4th Cir. 1987) (quoting the factors to be considered from comment $c$ of $\$ 261$ of the Restatement (Secono) of Contracts) with Hawke's Bay Electric-Power Board v. Thomas Borthwick \& Sons Ltd., [1933] N.Z.L.R. 873, 883-84 (looking to language of contract and extrinsic evidence of parties' intent to resolve a contract allegedly breached due to frustration of purpose).

58. White \& Summers, supra note 51, at 180-81; accord James J. White, Contract Law in Modern Commercial Transactions, An Artifact of Twentieth Century Business Life?, 22 WAshbu RN L.J. 1, 3-4 (1982).

59. FARNSWORTH, supra note 47 , at 572. 
least with regard to long-term contracts. ${ }^{60}$ They can draw on some instances of even more content-oriented standards of validity, such as the price adjustment imposed in the $A L C O A$ case, and on section 272 of the Restatement (Second) giving courts the power to "grant relief on such terms as justice requires, including protection of the parties' reliance interests," if this is necessary to "avoid injustice." Very few U.S. judgments have gone this far ${ }^{61}$ However, the $A L C O A$ case drew on a brief prepared by Allan Farnsworth, the eminent Chief Reporter for the Restatement, and has since generated a deluge of commentary helping to keep it in the minds of judges and lawyers, ${ }^{62}$ generating a small but steady stream of cases seeking all sorts of relief even on the basis of extreme market price fluctuations. ${ }^{63}$ In England, and perhaps especially New Zealand, in the light of cases like Gore, the significantly stricter approach of the courts is probably a major reason for the paucity of litigation on this point. ${ }^{64}$

\section{Japanese Law: Non-Imputable Impossibility and the Doctrine of Changed Circumstances}

Like U.S. law, Japanese law has long recognized the possibility of relief in the event of extreme economic dislocation. ${ }^{65}$ On one hand, this can follow from Article 415 of the Civil Code, which provides that the promisor becomes liable for damages if performance becomes impossible for any cause attributable to him or her. By reverse implication, the promisor will not be liable for non-attributable

60. See, e.g., Richard E. Speidel, The New Spirit of Contract, 2 J. L. \& Coмm. 193, 206-08 (1982).

61. Farnsworth, supra note 47, at 579-80; see E. Allan Farnsworth, Developments in Contract Law During the 1980s: The Top Ten, 41 CASE W. Res. L. Rev. 203, 213-16 (1990). For a representative critique, see, e.g., John P. Dawson, Judicial Revision of Frustrated Contracts: The United States, 62 B.U. L. Rev. 1 (1984).

62. See, e.g., Macaulay ET al., supra note 51, at 1181-93.

63. Compare Oglebay Norton Co. v. Armco, Inc., 556 N.E.2d. 515, 517 (Ohio 1990) (declaratory judgment action seeking affirmation of contract rate as "the correct rate" following industry downturn) with McLauchlan, supra note 35, at 96-97.

64. Compare Treitel, supra note 21, at 255-65 with Power Co. Lid. v. Gore District Council, [1997] 1 N.Z.L.R. 537, 540-41 (refusing to treat inflation as a fundamental change consistent with the doctrine of frustration).

65. For general discussions of the doctrines of impossibility and frustration in Japanese law, see J. Toshio Sawada, Subsequent Conduct and Supervening Events: A Study of Two Selected Problems in Contract Jurisprudence 133-61 (1968); Kiyoshi Igarashi \& Luvern V. Rieke, Impossibility and Frustration in Sales Contracts, 42 WASH. L. Rev. 445 (1967); Paul Waer, Frustration of Contracts in Japanese Law: The Doctrine of Changed Circumstances, 20 L. JaPAN 187 (1987). 
performance (for instance by an act of God or another event beyond his or her control). Here, impossibility has long been interpreted as including not only physical impossibility, but also impossibility in the light of "common sense in society" (shakai tsunen). Thus, a promisor could be excused if performance of his or her obligation would incur extremely high labor or other costs (e.g., the seller of a diamond ring drops it in the middle of a lake). ${ }^{66}$

On the other hand, the more recently developed "doctrine of changed circumstances" (jijo henko no gensoku) has proven more popular in providing relief where costs of performance have increased dramatically and also where the market price of the subject matter of the contract (such as land) has fluctuated widely. The doctrine was developed at first by Japanese academics drawing on German legal theory, itself rooted in the wake of hyperinflation after World War I and bolstered by the German Civil Code's express recognition of a generalized duty of good faith. The Japanese doctrine came to be recognized by the courts toward the end of World War II and during the decade of economic turmoil and reconstruction that followed.

One prerequisite for the doctrine is a substantial change in circumstances affecting the basis of the contract. A second prerequisite, sometimes related in that it can involve weighing any resultant disequilibrium in contractual obligations, is that strictly enforcing the promisor's original obligation would be highly unfair in light of the principle of good faith. Although mainly in older cases, courts have found these hurdles to have been cleared often enough for claims of relief under the doctrine to continue appearing before Japanese courts, including in cases involving commercial impracticability. However, significant numbers have failed, sometimes because of further hurdles such as the prerequisites that the changed circumstances not be attributable to the promisor and that they not be foreseen or foreseeable.

The latter requirement, in particular, is criticized by Japanese commentators, following the view accepted by commentators and some courts in the United States that foreseeability should only be a factor in deciding whether the promisor has assumed the risk that eventuated. This more flexible approach appears in some lower court decisions.$^{67}$ However, the Supreme Court seems to have taken a stricter view in a recent case.$^{68}$ It rejected a defense of changed circumstances put

66. Hiroyuki Kubo, A Comparative Study of the Basic Concept of Impossibility Under Japanese, American and Uniform Law, SANDAI Hocaku 567 (1991).

67. See, e.g., Hiroyuki Kubo, Keizai Hendo to Keiyaku Riron [Economic Change and ConTRACT Theory] (1992).

68. Sato \& Ors. v. Painu Hiruzu Gorufu K.K., 953 Hanrei talmuzu 99 (Sup. Ct., July 1,1997). 
forth by a golf course management company. A group of club members had sued seeking a declaration of their continued rights to use the golf course facilities and transfer rights after the company tried to levy further funds to pay for extensive construction work related to major subsidence problems on the property. The Court held that the defendant company had not proved that its predecessors had not foreseen the possibility of subsidence. This restatement of orthodox principle, and the holding itself, nonetheless may have been dictated by the way in which the case came before the Supreme Court. It had involved a claim by members and a defense of changed circumstances by the management company (impliedly seeking termination of the club member's membership rights). One commentator points out that the company might have succeeded if it had been the one bringing suit, also invoking the doctrine of changed circumstances, but seeking only an adjustment in the rights and obligations on both sides. ${ }^{69}$

This leads to the important point that under the law in Japan, as in the United States, a right of adjustment is recognized as a possible consequence of applying the doctrine. Indeed, as originally proposed by academics, this was to be the primary effect, with termination following only if adjustment was not achievable. In fact, in a survey of the sixty-four reported cases (as of 1994) in which the doctrine had been invoked, only thirteen first sought adjustment and otherwise termination; twenty-eight cases simply claimed termination. On the other hand, contract adjustment alone was claimed in twenty cases. Of these, adjustment was allowed by the courts in nine cases; and, out of the thirteen seeking adjustment and otherwise termination, adjustment was allowed in four cases. ${ }^{70}$ This may seem activist, when compared to rare examples in the United States such as $A L C O A .^{71}$ But it should be noted that court adjustment in Japan has been by the lower courts (never by the Supreme Court), always within the range proposed by one or both parties, and predominantly in earlier cases (arising during or from World War II). ${ }^{72}$ Partly in the hope of providing more legitimacy and background for courts

69. Hiroyuki Kubo, Jijo Henko no Gensoku to Yoken Kanosei-Seme ni Kisubeki Jiyu no Yoken [The Doctrine of Changed Circumstances and Requirements of Forseeability and Non-Imputable Cause], 208 Hogaku Kyoshitsu 100 (1999).

70. K. Iijima, Jijo Henko no Koka to shite no Keiyaku no Tekigo to Kaijo [Recission and Adjustment of Contracts as Effects of the Doctrine of Changed Circumstances], 35 Toritsuda Hogakrai Zasshi 127 (1994).

71. Aluminum Co. of Am. v. Essex Group, Inc., 499 F.Supp. 53 (W.D. Pa. 1980).

72. See generally Luke Nottage, Economic Dislocation and Contract Renegotiation in New Zealand and Japan: A Preliminary Empirical Study, 26 Victoria U. Wellington L. Rev. 59 (1997) (reporting results from studies into attitudes and practices in New Zealand and Japan as to the effect extreme economic hardship should have on contracts). 
adjusting contracts under the doctrine of changed circumstances, as well as permitting more scope for party autonomy during the course of performance, various scholars recently have suggested a duty to renegotiate in good faith. ${ }^{73}$ The contours of such a duty remain unclear, however, and these suggestions mostly are made in the context of much broader theoretical debates. Meanwhile, the notion of a duty to renegotiate has not been clearly affirmed even by lower courts. ${ }^{74}$

Nonetheless, the potential for greater flexibility resulting from the doctrine of changed circumstances in principle permitting court adjustment may help explain, as in U.S. law, the somewhat greater readiness to apply the doctrine compared to the law of frustration in England or New Zealand. Likewise, the willingness to extend the Civil Code notion of impossibility from physical to practical impossibility-although there is far less reported case law decided on that basis-may be tied to the fact that allowing an excuse on this ground does not automatically terminate the contractual relationship. Instead, as in U.S. law, ${ }^{75}$ the effect on the other party, for instance, as to its rights of termination, is determined as if there had been a breach usually requiring the other party to give notice and so on.

Although beyond the scope of this study, the Australian law of frustration appears similar to English and New Zealand law in its conceptual basis and restricted scope of application. ${ }^{76}$ This helps explain the following remark by an Australian commentator in discussing contract disputes involving Japan and Australia in the early 1970s:

There was the added risk that the Japanese courts might refuse to enforce the Australian judgment based on radically different law

73. Yamamoto Keizo, Minpo Kogi Iv-1 KeIYaku [Civil Law Lectures, Vol. IV-1, Contracts] (2005) 109-11.

74. See id.

75. Not surprisingly, in the light of its heavy influence on Japanese contract law, this is also the approach in German law. See generally G.H. Treitel, UNmöglichkeit, "I MPRACticability" und "Frustration" im Anclo-Amerikanischen Recht (1991).

76. See J.W. Carter \& D.J. Harland, Contract Law in Australia 711-61 (3d ed. 1996) (discussing the parameters of the doctrine of frustration). But see the result in Codelfa Construction Pty Ltd. v. State Rail Authority of New South Wales (1982) 149 C.L.R. 337 (despite adopting a similar test to that in Davis Contractors Ltd. v. Fareham Urban Dist. Council, [1956] A.C. 696, 728 (H.L.) (appeal taken from Eng.) (U.K.) and Power Co. Ltd. v. Gore District Council, [1997] 1 N. Z.L.R. 537, namely, whether the situation was fundamentally altered from that provided for on a "true construction" of the original contract, signaling a somewhat more liberal approach). 
[favoring strict contractual liability] from that which the Japanese courts recognize as applicable in the circumstances. ${ }^{n}$

Nonetheless, describing Japanese law as "radically different" is clearly an overexaggeration. As previously mentioned, both the doctrine of non-attributable impossibility and the doctrine of changed circumstances have requirements, such as unforeseeability, which are common to the law of frustration. Japanese courts, especially the Supreme Court, are also reluctant to apply both doctrines to relieve promisors. The contemporary law of frustration in England and New Zealand, and perhaps Australia, may be even stricter, but Japanese law appears only somewhat more lenient than U.S. law. Correctly, John Haley criticized some others' suggestion that Japanese law is decidedly more liberal than U.S. law with respect to the doctrine of non-attributable impossibility. ${ }^{78}$ Later, echoing the now shared understanding among Japanese academics and commentators, Haley also acknowledged the Supreme Court's reluctance to apply the doctrine of changed circumstances, and concluded: "The courts do not readily accept excuses. The courts implicitly agree that certainty and consistency are community values. Particularized justice is not an overriding concern." 79

\section{CISG and UPICC Compared}

The CISG regime has also turned out not to allow relief for supervening external events in international sales except in exceptional situations. The 1980 Convention came into effect in 1988 and has since grown increasingly popular. It now has around seventy Member States including all of the world's major trading nations-except England and Japan (where, however, the Ministry of Justice has committed to implementing it by 2008). This makes it increasingly likely that CISG's rules on contract formation, performance, and breach apply. That is because the Convention applies to sales of goods concluded between parties in different Member States (Article 1(1)(a)), as well as where the private international law rules of the forum (court or arbitral tribunal) lead to the application of the law of a Member State (Article 1(1)(b)), unless the forum state has made a reservation disallowing this route.

77. P.H.N. Opas, What Happens When the Contract Becomes Unprofitable?, 1 Aust. Bus. L. Rev. 59, 62 (1973) (emphasis added).

78. John Owen Haley, The Spirit of Japanese Law 172 (1998).

79. Id. at 76 (emphasis added). 
The CISG regime has turned out to be quite a successful compromise between civil law and common law traditions, despite some-partially intentional-vague drafting. For example, attempting to make it more attractive to those in the English law tradition, the CISG does not directly impose obligations of good faith on parties to its contracts. Instead, Article 7(1) requires the Convention itself to be interpreted so as to promote the observance of good faith in international trade. Article 7(2) adds that if there are clear gaps in the Convention, these should be settled "in conformity with the general principles on which it is based" (or otherwise the applicable domestic law), which may include "reasonableness" or good faith obligations on parties. Showing even more deference to Anglo-American law, CISG generally adopts a unitary strict-liability concept of breach; unlike in some civil law countries, lack of fault is no excuse, even in relation to certain types of breaches.

In addition, the window in Article 79 for providing relief from changed circumstances is quite narrow. The party must prove an "impediment ... beyond his control, ... which he could not have reasonably be expected to have taken ... into account at the time of conclusion of the contract" or "to have avoided or overcome it or its consequences." Legislative history shows that the word "impediment" was used in CISG to set a more objective and higher standard to trigger relief. Courts and arbitrators from around the world have generally followed this notion, with one tribunal suggesting that the impediment must amount to "an unmanageable risk or totally exceptional event." ${ }^{\text {' }}$ "This underpins a strong reluctance to find changes primarily to economic circumstances to amount to a sufficient impediment. For example, that tribunal held a Hong Kong seller to its contract with a German buyer and distributor despite its supplier encountering extreme financial difficulty, causing it to discontinue producing the goods unless the seller provided it with considerable financing. Likewise, a buyer of steel rope was not allowed relief from payment obligations due to adverse market developments and decreased trade in its industry, problems storing the goods, and currency revaluation. ${ }^{81}$

80. Chinese Goods Case (H.K. v. F.R.G.), CLOUT case No. 166 (Schiedsgericht der Handelskammer Hamburg 1996), available at http://cisgw3.law.pace.edu/cases/96032lgl.html; see also U.N. Comm'n on Int'l Trade Law, UNCITRAL Digest, II 10, U.N. Doc. A/CN.9/SER.C/DIGEST/CISG/79 (Jun. 8, 2004) [hereinafter UNICTRAL Digest]; Pace Law School Institute of International Commercial Law, CISG Database, Legislative History: 1980 Vienna Diplomatic Conference, http://www.cisg.law.pace.edu/cisg/article-by-article.html (last visited May 15, 2007) (providing the legislative history of each article of the CISG).

81. Steel Ropes Case (Russ. v. Bulg.), No. 11/1996 (Bulgarska turgosko-promishlena palata 1998), available at http://cisgw3.law.pace.edu/cases/980212bu.html. 
In the first case, the arbitrators also found that such commercial risks were "not beyond control" of the seller. In the second case, the circumstances were also found not to be "unforeseeable." These more specific hurdles have been applied in several other cases to refuse relief particularly for commercial impracticability. ${ }^{82}$ In a recent Belgian judgment, the court held that a seller of rolled steel tubes was still bound to supply despite increased supply costs, reasoning that this was foresecable in that trade and that parties could contract otherwise through force majeure clauses-including via CISG Article 6 . The Court pointed out that domestic Belgian law also now declines to extend general notions of good faith to allow relief in such circumstances. Although this aside was linked to the general rationale of promoting certainty in legal dealings, potentially applicable to both domestic and international sales, it may also reflect a certain "homeward trend" among local courts interpreting this international instrument. ${ }^{83}$

Nonetheless, the case law confirms the predominant view of commentators that CISG Article 79 should extend to commercial impracticability in extreme situations. That is not a gap, as described in Article 7, which needs to be filled by other law, especially not an otherwise applicable domestic law. ${ }^{84}$ Overall, although still infrequently, Article 79 relief does seem to be allowed more often than in the English law tradition. Further, the case law-especially from civil law jurisdictions-quite often draws expressly or impliedly on a general principle of good faith in contractual relations. For example, a German judgment refused to excuse the seller's failure to deliver tomatoes after heavy rainfalls damaged the local crop and raised prices, reasoning that these were impediments that could have been overcome; rather the Court appeared concerned about the seller's lack of good faith. ${ }^{85}$ If the seller had at-

82. UNCITRAL Digest, supra note 80, at II 10, 13, 15; see also Valero Mktg. \& Supply Co. v. Greeni Oy, 373 F. Supp. 2d 475, 478 n.5 (regarding petroleum products); Pace Law School Institute of International Commercial Law, CISG Database, Article 79: UNCITRAL Digest Cases Plus Added Cases, http://www.cisg.law.pace.edu/cisg/text/digest-cases-79.html (last visited May 15, 2007) (providing recent Article 79 case law).

83. See, e.g., Scaforn Int'l B.V. \& Orion Metal BVBA v. Exma C.P.I. S.A. (Belg. v. Fr.), A.R. A/04/01960 (Rechtbank van Koophandel Tongeren 2005), available at http://cisgw3.law.pace.edu/ cases/050125bl.html.. For a discussion of the persistence of the homeward trend in U.S. courts, see Larry DiMatteo et al., International Sales Law: An Analysis of CISG Jurisprudence 174-77 (2005); Larry DiMatteo et. al., The Interpretive Turn in International Sales Law: An Analysis of Fifteen Years of CISG Jurisprudence, 24 Nw. J. INT'L L. \& Bus. 299, 437-39 (2004).

84. John O. Honnold, Uniform Law for International Sales under the 1980 United Nations Convention I 432.2 (3d ed., 1999).

85. "All the evidence seems to indicate that the [seller] only wanted to gain profit from the increased prices for tomato concentrate due to the market shortage. Even though the [seller] does not put forward a total loss of the harvest but merely a proportional decline, the [seller] did not even 
tempted a reasonable reallocation, as allowed under U.S. law or, arguably, Japanese law, Article 79 might have provided relief, whereas Anglo-New Zealand law would always disallow such frustration as "self-induced."

Greater potential, at least, to obtain relief under CISG arguably is linked to the less drastic effects of applying Article 79. It merely provides an excuse or exemption for damages claims. The contract is therefore not automatically terminated or rendered void. The impediment, for example, if seemingly temporary, must amount to the equivalent of a "fundamental breach," defined in Article 25, in order to trigger avoidance, which, as always, must be expressly sought by the party seeking to terminate the contractual relationship. In addition, Article 79(4) always requires further notice by the party seeking exemption from damages, informing the other party of "the impediment and its effect on his ability to perform." ${ }^{\prime 6}$ This also serves to keep the contract alive between the parties-the favor contractus general principle found also in case law and commentary in situations of unexcused breach. Structurally, therefore, Article 79 is very similar to U.C.C. section 2-615 in U.S. law.

UPICC goes a step further toward more substantive reasoning in the time dimension. Article 7.1.7 on "force majeure" basically reproduces CISG Article 79.87 But UPICC Article 6.2 adds further relief for "hardship." That is defined as subsequent price-cost fluctuations that fundamentally alter the contractual balance, and which are beyond the party's control and ability to take into account when forming the contract-hence, risks not assumed by that party. Comment 6 notes that this may overlap with Article 7.1.7 force majeure. But it appears that the bar to relief is being lowered in Article 6.2. In particular, the effects of applying it are even less drastic. Rather than immediate exemption from damages and then possible termination, for example, Article 6.2.3 allows the affected party first to request negotiations and then to obtain either termination or adjustment of contract

offer the [buyer], who was already a customer of the [seller], a proportion of the harvest at the old price." Tomato Concentrate Case (Fr. v. F.R.G.), 1 U. 143/95, 410 O. 21/95 (Oberlandesgericht Hamburg 1997), available at http://cisgw3.law.pace.edu/cases/970704gl.html.

86. Convention on Contracts for the International Sale of Goods art. 79, I 4, Apr. 11, 1980, 1489 U.N.T.S. 3.

87. For a match-up of CISG Article 79 provisions with counterpart provisions from the UNIDROIT principles and additional commentaries, see Pace Law School Institute of International Commercial Law, CISG Database, Use of the UNIDROIT Principles to Help Interpret CISG Article 79, http://www.cisg.law.pace.edu/cisg/principles/uni79.html (last visited May 16, 2007). For additional analysis of the CISG and similarities between its provisions and the UNIDROIT Principles, see Sarah Howard Jenkins, Exemption for Nonperformance: UCC, CISG, UNIDROIT Principles-A Comparative Assessment, 72 Tul. L. Rev. 2015, 2027-29 (1998); Dietrich Maskow, Hardship and Force Majeure, 40 Aм. J. Сомp. L. 657, 663-65 (1992). 
terms by the court or arbitrators. In other words, this is similar to the outer limits of U.S. law (court adjustment in the $A L C O A$ case and some commentators' advocacy of a duty to renegotiate in good faith) and the doctrine of changed circumstances (especially regarding court adjustment) that Japanese law, extending German law and notions of good faith, has superimposed on the older "impossibility of performance" doctrine. Likewise, UPICC Article 1.7 imposes a duty of good faith directly on the contracting parties, which, moreover, they cannot derogate from if they adopt the UPICC.

UPICC can take this more radical step, compared to CISG (with its opt-out regime), because this soft law generally only applies if specific contract parties opt in to the regime by expressly incorporating the Principles into their contract. ${ }^{88} \mathrm{Argu}-$ ably, too, such additional provisions are needed since the Principles are designed to apply to all international commercial contracts rather than just sales of goods, thus including more relational long-term services contracts and the like that call for more flexibility in contractual dealings. This allows for a more substantive orientation, since UPICC need not pander so much to the stricter English law tradition.

Nonetheless, especially as case law slowly accumulates, in some respects, UPICC may promote more formal reasoning than CISG, for example, when they cover the same ground with similar effects but more detailed "triggers" (e.g., regarding applicable interest rates or factors indicating when specific performance is appropriate). More importantly for present purposes, it seems likely that courts and arbitrators will remain cautious about applying UPICC's hardship provisions. Even if parties have expressly adopted UPICC, it could be argued that they were not necessarily so convinced about Article 6.2. After all, hardship clauses in transnational contract law practice, although quite common, are less used than force majeure clauses, which tend to have less coverage and interventionist effects. Reticence to apply Article 6.2 should also be more pronounced where courts and, especially, arbitrators refer to UPICC not because the parties required it by agreement, but as persuasive or indicative of practices and norms in trans-border commercial dealings. ${ }^{89}$

Overall, however, UPICC thus far has more potential than CISG to favor

88. See generally Luke Nottage, Legal Harmonization, in InTERnational EncycLopedia of LAW and the Social Sciences (David Clark ed., forthcoming 2007).

89. Compare Jennifer M. Bund, Note and Comment, Force Majeure Clauses: Drafting Advice for the CISG Practitioner, 17 J.L. \& Coмm. 381 (1998) (arguing that UNIDROIT hardship provisions serve a gap-filling role for the CISG doctrine of excuse), with Nottage, Who's Afraid of the CISG?, supra note 3, and Pace Law School Institute of International Commercial Law, CISG Database, Annotated Text of CISG Article 79, http://www.cisg.law.pace.edu/cisg/text/e-text-79.html (last visited May 16, 2007). 
substantive reasoning in regard at least to supervening external events affecting longer-term contracting. Given the continued paucity of UPICC case law, it is debatable whether this means it is more or less substantive than U.S. law, which is somewhat less substantive than Japanese law. Bur UPICC, and even CISG, are quite distant from the other end of the spectrum, where formal reasoning prevails both in England and New Zealand.

\section{III. “Didactic Formality": Another Variety of Formality}

The foregoing demonstrates the ready applicability of the form-substance distinction proposed by Atiyah and Summers in yet another important area of contract law in broad comparative and transnational context. By revealing important similarities with U.S. law, the analysis also undermines suggestions-like the following - that Japanese law is distinctly more open to contract renegotiation: "Instead of trying to spell out all possible contingencies and provisions for enforcement in inflexible terms, the Japanese prefer to handle problems as they arise, often recognizing the doctrine of 'changed circumstances." $\$ 0$

Although seemingly referring to a legal doctrine (jijo henko no gensoku), this remark can be read as an assertion about the lay attitudes of Japanese contracting parties. Indeed, Robert March goes on to mention the Ajinomoto soybean dispute as demonstrating an alleged penchant among Japanese businesses for informality in contract formation. ${ }^{91}$ This echoes the late Takeyoshi Kawashima, Japan's leading post-War legal sociologist, who famously introduced the judgment to suggest that the Japanese held a uniquely non-Western "contract consciousness. ${ }^{\text {"92 }}$ March also discusses in detail the Australia-Japan Sugar Case, drawing various conclusions, such as "[l]ong-term contracts with the Japanese suffer, in Western eyes,

90. Robert M. March, The Japanese Negotiator: Subtlety and Strategy Beyond Western LoGic 112 (1988) (emphasis added).

91. Id. at $97-107$.

92. Compare Takeyoshi Kawashima, The Legal Consciousness of Contract in Japan, 7 Law IN Japan 1, 2-3 (Charles R. Stevens trans., 1974) (discussing the "consciousness of contract" the Japanese have with regard to concluding a contract), with Luke R. Nottage, Japanese Contract Law, Theory and Practice: Plus ça change, plus c'est la même chose?, in Asian Laws Through AustraLIAN Eyes 316 (Veronica Taylor ed., 1997) (examining the impact of Kawashima's views on early perceptions in Australia and New Zealand, as well as on contemporary contract law theorists in Japan), and Nottage, Formal Requirements, supra note 6, Part II.D (locating the Ajinomoto case in the broader context of flexible writing requirements in Japanese contract law). For a case study illustrating the Japanese perspective, see МАRCH, supra note 90, at 97-107. 
from the Japanese refusal to honor the contract when circumstances change. This view of distinctly Japanese attitudes toward contract often parallels similar views of Japanese contract law, and Japanese law generally, as unique or unusual. Recent empirical studies, however, allow such attitudes to be gauged more systematically, in broader comparative perspective. ${ }^{94}$

As well as forcing stereotypes to be revised, these studies allow Atiyah and Summers' framework to be expanded. ${ }^{95}$ Another important way in which New Zealand and English law appear to differ significantly from both Japanese and U.S. law is in its greater "didactic formality."

\section{A. Preliminary Comparative Empirical Studies}

Concerns primarily about lingering stereotypical views regarding Japanese attitudes toward contract renegotiation led to an ambitious multinational survey of 23,885 law and business students in twenty-two jurisdictions, implemented between 1994 and $2000 .{ }^{96}$ It tested their attitudes toward the actions of parties in a hypothetical contract renegotiation situation modeled on the Australia-Japan Sugar Case. Basically, a buyer agrees to a five-year contract at a price fixed at half the then market price (a good deal), then attempts to renegotiate after the market price drops well below the fixed price one year later (turning it into a bad deal). ${ }^{97}$ Intriguingly, there were almost no statistically significant differences between students in Japan compared to England, New Zealand, and the United States. All were quite lenient, for example, in response to question $\mathrm{E}$, posed midway through the scenario, suggesting that the buyer's attempts to force renegotiation "should not be supported because one should observe terms once a contract is made." ${ }^{\prime 8}$

93. МARch, supra note 90 , at 97 (emphasis removed).

94. See infra Part III.A.

95. See infra Part III.B.

96. Akira Fujimoto, 22-ka-koku-chiiki Keiyaku Ishiki Chosa ni Tsuite [The Survey of Contracts Consciousness in 22 Countries or Areasl, Nagoya Daigaku Hosei Ronshu 115.

97. See generally Nihonjin no Keiyakukan [Japanese Conceptions of Contracts] (Masanobu Kato \& Akira Fujimoto eds., 2005) (giving an overview of the final data, across 15 countries); Nottage, supra note 72 (preliminary comparison of data from New Zealand); Michael K. Young et al, Japanese Attitudes Towards Contracts: An Empirical Wrinkle in the Debate, 34 Geo. WASH. INT'L L. Rev. 789 (2003) (analyzing data from Japan).

98. Fujimoto, supra note 96, at 158 (Table 3-6). The average for Japanese students was 2.71 (i.e., slightly more disagreed than agreed with this proposition). The average was 3.29 when the question was rephrased as "whether the buyer's attempts to renegotiate should be supported despite the pacta sunt servanda principle" (i.e., slightly more would have agreed than disagreed that the principle should not be strictly applied), indicating a more flexible "contract consciousness" among the 
A much smaller-scale mail survey of Japanese and New Zealand companies conducted soon after the survey of students suggested that they were reasonable proxies for company personnel in each of the two countries. However, the New Zealand companies were slightly tougher on the buyer in the same scenario based on the Sugar Case compared to Japanese companies. ${ }^{99}$ This mail survey also asked what a court should do when faced with a scenario based on the ALCOA case where the seller is the one attempting to get out of a long-term fixed-price contract due to commercial impracticability. New Zealand companies were stricter than Japanese companies in deciding that the court should not allow an excuse. Their reactions were similar to those of in-house legal counsel surveyed in the United States in $1988 .{ }^{100}$ Correspondingly, somewhat more Japanese respondents thought the court should adjust the contract. ${ }^{101}$ Nonetheless, around half of both U.S. and New Zealand companies preferred court adjustment, which is rare in U.S. courts and unheard of in Anglo-New Zealand contract law.

The mail survey of New Zealand and Japanese companies also added questions about other expectations in contractual relationships, as well as certain practices, which were derived from the U.S. survey. Generally, New Zealand respondents seemed quite flexible. Certainly, they undertook somewhat fewer contracts of one year or more in duration, compared to their Japanese and, especially, U.S. counterparts. Slightly more also insisted on compliance with the contract in response to a supplier or customer requesting a modification in price because of a shift in market prices. Yet the overwhelming majority did not insist

Japanese students. Yet, when similarly rephrased, the average for students from the United States was 3.39, from England, 3.49, and from New Zealand, 3.53. This suggests even less strict contract consciousness among students from those countries, although the differences between their averages and the average from Japan is not statistically significant at the $95 \%$ confidence level. Id. at 163-64. The key point is that students from all countries are quite lenient regarding contract renegotiations following market price changes, which is rather unexpected especially in the more formal-reasoning based Anglo-New Zealand systems. See infra Part III.B.

99. See Nottage, supra note 72; see also Luke Nottage, Planning and Renegotiating Long-Term Contracts in New Zealand and Japan: An Interim Report on an Empirical Research Project, 1997 N.Z. L. Rev. (Special Issue) 482 (exploring the possible force of a range of norms in New Zealand and Japan).

100. For an explanation of that study and its results, see Russell J. Weintraub, $A$ Survey of Contract Practice and Policy, 1992 WIs. L. Rev. 1, 41-45 (1992).

101. In a roughly contemporaneous mail survey only of Japanese companies, using almost the same scenario but asking what the hypothetical buyer should do, a similar proportion indicated lenience towards the seller. See Shugo Kitayama, Keizokuteki Torihiki ni kansuru Kokunai Anketo Chosa no Kekka [Results from a Domestic Mail Survey of Continuing Transactions] (Part Three), 630 NBL 52, 59 (1997). 
on this, with the most frequently cited factor relevant to this situation being--as in the United States- “long and satisfactory" relations with that party. Certainly, too, New Zealand firms were more likely than Japanese and U.S. firms "never" themselves to have asked for relief from, or modification of, contractual obligations. When, however, they did, the most common experience-as in the United States and Japan-was "amicable working out of the problem by modification of the performance of the contract in question." Such flexible attitudes toward contractual obligations also emerged from several follow-up interviews. ${ }^{102}$

Care must be taken in interpreting this empirical research. In the company surveys, the samples are small, the main business sectors covered in each are not identical, and the U.S. survey focused solely on legally trained company personnel, who may well hold different attitudes than businesspeople as a whole. ${ }^{103}$ Even the large-scale student survey was not based on random sampling, so the results are not necessarily representative of underlying populations in each country. Nonetheless, all survey results seem to overlap considerably and to fit with other empirical studies suggesting that contract law in action is significantly more flexible than the law in books--even in the English law tradition. ${ }^{104}$

\section{B. The "Law in Books" Trying to Lead the "Law in Action"}

Such a gap between law and practice is more problematic for Atiyah and Summers because it seems quite large in a form-oriented legal system like New Zealand's, as well as in more substantive systems like those in Japan and the United States. In addition to various dimensions of legal reasoning per se, Atiyah and Sum-

102. Nottage, supra note 72.

103. Whether legally trained personnel will be tougher or more lenient is difficult to predict. Lawyers generally seem more likely to stick more strictly to the law. See, e.g., Foote, supra note 2 (citing Whitmore Gray, The Use and Non-Use of Contract Law in Japan: A Preliminary Study, 17 Law in JAPAN 98 (1984)). But the student survey found many countries where business students held stricter attitudes than law students. NiHONJIN No KeIYAKUKan, supra note 97, at 89-98. This was especially evident in New Zealand and, to a slightly lesser extent, the U.S. and Japan. See Young et al, supra note 97. However, the tendency was less noticeable in England (and several other Commonwealth legal systems-Australia, India, and Hong Kong), perhaps again reflecting a more formal approach to law and legal education.

104. For a famous example in the United States, see Stewart Macaulay, Non-Contractual Relations in Business: A Preliminary Study, 28 AM. Soc. Rev. 55 (1963) (discussing a survey that revealed businessmen often fail to plan exchange relationships completely and seldom use legal sanctions to adjust the relationships or settle disputes). For a similar example in England, see Hugh Beale \& Tony Dugdale, Contracts Between Businessmen: Planning and the Use of Contractual Remedies, 2 BrIt. J.L. \& Soc'y 45 (1978). 
mers had contrasted two broader "varieties of formality" in England and the United States: "enforcement formality" and "truth formality."10s "Enforcement formality" was defined as the degree to which legal rules and other norms are actually translated into practice. ${ }^{106}$ More formal legal systems strive to ensure a higher degree of obedience to the law and its enforcement. Atiyah and Summers contrasted, for example, the relative speed and efficiency of English as opposed to U.S. court practice. "Truth formality" was defined as the degree to which a legal system identifies "true facts" to which legal rules and other legal phenomena are related. ${ }^{107}$ Atiyah and Summers suggested that all legal systems strive to recognize this to a degree, to implement rules of law embodying underlying substantive social policies, for instance, and to allow, even in formally oriented systems, judges encountering concrete social realities to bring the law up to date. They argued, though, that the trial process in English law overall exhibits more truth formality. These two varieties of formality, which arguably are very prevalent in New Zealand as well, should help generally in bringing the law in books closer to the law in action.

The gap may indeed be smaller in the field of contract renegotiations than is suggested by the empirical studies outlined earlier in this article, ${ }^{108}$ due to their scale, design, or interpretation. It is also possible that the gap has closed somewhat over the decade since these surveys were carried out, along with a broader juridification of socio-economic relations. Alternatively, a persistent and significant gap here, and possibly in other areas of Anglo-New Zealand contract law and practice, can be admitted, but Atiyah and Summers' framework needs to be amended by proposing a third type of formality. The strict attitude of New Zealand courts in this area can be considered as exhibiting "didactic formality." This develops an idea relegated to a footnote at the start of their discussion of trial processes in England and the United States, where Atiyah and Summers remark, without elaboration: "Lawyers who remain preoccupied with 'law in books' when it really does not represent 'law in action' may also be accused of taking an excessively 'formal' view, in a rather different sense."109

Didactic formality can be defined as the preference-or hope, however forlorn-for any remaining gaps between law in books and law in action to be lessened by the latter (social practices and expectations) coming to accord with the

105. Atiyah \& Summers, supra note 1, at 17-18.

106. Id. at 18 .

107. Id.

108. See infra Part III.A.

109. Atiyah \& Summers, supra note 1 , at 158 n.3. 
former, rather than vice versa. Such formality can be expected to be greater in a legal system with higher degrees of other types of formality, such as enforcement and truth formality, as well as the dimensions of reasoning suggested by Atiyah and Summers.

Thus, New Zealand courts hope that by denying relief in cases like Gore, ${ }^{110}$ parties concluding long-term supply contracts will become more careful in planning and drafting for contingencies, obviating the need for adjustment during performance. Moreover, by not readily enforcing a variety of informal agreements, they hope to channel contracting party behavior toward more formalization. Finally, the courts hope that by awarding relief for contractual unfairness in only the most egregious cases, consumers and others will come to negotiate fairer terms in their contracts, or at least take more care in their dealings.

English courts, still reluctant to recognize a general duty of good faith in contract law or even to revive the doctrine of unconscionable bargains, exhibit this attitude too. ${ }^{111}$ The decline of the doctrine of frustration in recent decades can be seen, again, as the courts trying to encourage parties to plan more carefully for contingencies. ${ }^{112}$ This is especially so now that the types of triggering events (wars, strikes, nationalizations, embargos, and so on) have become more well known. As noted by Treitel in relation to commercial impracticability:

English law has tended to place greater emphasis than American law on the ... requirements of certainty and of the sanctity of contract, even though the result of doing so might occasionally appear to be harsh to one of the parties. It seems that mitigation of such hardship should, in the view of the English courts, be achieved not by a broad doctrine of discharge, uncertain in its operation, but by express con-

110. Power Co. Ltd. v. Gore District Council, [1997] 1 N.Z.L.R. 537.

111. Nottage, Who's Afraid of the CISG?, supra note 3; Nottage, Formal Requirements, supra note 6.

112. See infra Part II.A. This appears to be of little effect, at least among suppliers of manufactured goods in the United Kingdom, according to interviews of 16 companies carried out in 1993 1994 as part of a broader comparative empirical study. None of them included hardship clauses in their contracts with other companies, in sharp contrast to the 23 German companies interviewed (68\% of which did so). Simon Deakin et al., Contract Law, Trust Relations, and Incentives for Cooperation: A Comparative Study, in Contracts, Co-operation, and Competition: Studies in EcoNomics, Management, and Law 105, 118, 124 (Simon et al. eds., 1997). Additionally, there are gaps between English contract law and business practices and norms, which English courts and even law reformers seem uninterested in acknowledging or even investigating more systematically. See Richard Lewis, Contracts Between Businessmen: Reform of the Law of Firm Offers and an Empirical Study of Tendering Practices in the Building Industry, 9 J.L. \& Soc'Y 153 (1982). 
tractual provisions, or, in times of general economic dislocation (for example by war) through special legislative intervention. ${ }^{113}$

A high degree of didactic formality also helps explain the strictness of English courts in not giving effect to informal dealings, especially in cases involving charter-parties or ship sales when the words "subject to details" have been interposed. It is hard to believe that only English courts-yet not New York (Second Circuit) courts - are capable of correctly perceiving the practice and expectations in maritime commerce, or that the latter are so different in England compared to the United States. Rather, what seems to drive the English courts in this area too is the hope that by setting a bright-line rule, they will encourage commercial parties to negotiate and conclude contracts in conformity with those rules. ${ }^{114}$

This view of contemporary English contract law runs counter to suggestions that commercial bench judges are highly responsive to the expectations of international traders-giving them "what they want," namely very strict rules. ${ }^{115} \mathrm{~A}$ major difficulty with the proposition is its lack of empirical backing. International traders may still select English courts or arbitral tribunals mainly for historical reasons. The English legal profession may overexaggerate the advantages of these venues and stricter applicable rules more for their own benefit. Meanwhile, London is losing ground relative to other venues around the world for international commercial arbitration, which seems to be linked to stricter attitudes toward the flexible and evolving standards of the lex mercatoria. ${ }^{116}$

Another problem is that English law may have overgeneralized from perceptions-even if correct-of the expectations held by international traders, estab-

113. TREITEL, supra note 21 , at 260.

114. Nottage, Formal Requirements, supra note 6. Cf. Star Steamship Society v. Beogradska Plovidra (The "Junior K"), (1998) 2 Lloyd's Rep. 583, 585-86 (insisting that charter-party agreements negotiated "subject to details" are presumed not to have immediate binding effect, contrasting the more flexible approach of New York courts).

115. Len Sealy, Ties That Bind: Security of Contract in England at the End of the 20th Century, $16 \mathrm{~J}$. Cont. L. 47, 49 (2000).

116. See generally Nottage, Who's Afraid of the CISG?, supra note 3 (highlighting empirical data showing English respondents noticeably more reticent about use of broad principles of substantive lex mercatoria). For analysis of the expanding arbitration caseloads in the International Chamber of Commerce, based in Paris, and farther afield, outside London, see Christopher R. Drahozal, Regulatory Competition and the Location of International Arbitration Proceedings, in Towards a ScIEnce of International Arbitration: Collected Empirical Research 111 (Christopher R. Drahozal \& Richard W. Naimark eds., 2005); Luke Nottage, The Vicissitudes of Transnational Commercial Arbitration and the Lex Mercatoria: A View from the Periphery, 16 ARB. INT'L 53 (2000). 
lishing contract law rules that are then applied inappropriately in other contexts. ${ }^{117}$ Empirical studies of contract law in action show significant gaps between the law and both practices and expectations in many types of domestic transactions, such as manufacturing, construction, and dealings involving the public sector. ${ }^{118}$ Even commentators like Roy Goode, who sees the overall strength of English contract law as having included a responsiveness to business expectations, believes that they are now not being met in several areas, such as in regard to agreements to agree, suspension of performance, assurance of future performance upon future performance, and the all-or-nothing approach and limited scope for relief from commercial impracticability under the doctrine of frustration. In the latter respect, despite a reluctance to allow new generalized principles of good faith and substantive unconscionability into English law, he argues that it presents

a legitimate case for invoking a doctrine of substantive unconscionability. It would be inequitable for a party to seek to hold the other to the terms of the original bargain in the light of changed circumstances, and reasonable that the court should offer him the choice of accepting the modification or having it terminated by the court. ${ }^{119}$

Goode appeals to German law in support of this approach, which is also that of Japanese law, and to other European, U.S., and/or transnational law in criticizing all four areas in which contemporary English contract law is thought not to be meeting business expectations.

However, the reluctance to countenance broader standards and applicability of the doctrine of frustration has roots deep in English history. In 1916, in a case involving an increase in freight rates, Judge Scrutton insisted that it could only operate

117. Cf. Michael Bridge, Good Faith in Commercial Contracts, in Good Faith in Contract: ConCEPT AND Context 139, 147 (Roger Brownsword et al. eds., 1999) ("It is a fair reproach to English contract law that it unthinkingly treats the rules and principles of commodity sales, time and voyage charterparties and so on as though they could be applied without modification in very different contractual settings."). Such tendencies appear related to the fact that a significant majority of people in England appear to find judges to be out of touch with ordinary people's lives. In a largescale survey looking at access to civil justice generally, $66 \%$ thought this was so, $21 \%$ were uncertain, while only $13 \%$ thought they were in touch. Hazel Genn, Paths to Justice: What People Do and Think about Going to Law 239 (1999).

118. See generally Lewis, supra note 112 (discussing the extent to which businesses rely on the legal system to protect them in commercial transactions); Nottage, Japanisation of American Law?, supra note 2, at Part II.

119. Roy Goode, Commercial Law in the Next Millenium 37 (1998). 
upon "physical or legal prevention, not economic unprofitableness." ${ }^{20}$ It may be that he was in tune with commercial expectations in the shipping trade at the time, for Karl Llewellyn praised him for the robust business sense exhibited in the Judge's later writings. ${ }^{121}$ However, it is probably too late to know, and the more important question is whether businesspeople today would agree that commercial impracticability should not provide relief. What is clear is that commercial court judges, beginning with Judge Scrutton and continuing with Lord Justice Bingham in The Super Servant Two ${ }^{122}$ have stressed that parties concerned about hardship caused by the strict English doctrine should make contractual provision for future events. ${ }^{123}$ The didactic tone is unmistakable. Treitel also approves of such suggestions, noting how the Grain and Feed Trade Association standard form used in the grain trade had included elaborate provisions that were redrafted after they were held not to have covered a particular supervening event. ${ }^{124}$ However, Treitel's view that cases involving such clauses should be distinguished from those developing the general doctrine of frustration, and not influence the latter, runs counter to one argument presented by Jack Beatson in favor of abandoning a strict rule against allowing relief for commercial impracticability under English law:

The rules governing discharge for frustration are "default rules" provided by the law, and it is arguable that a default rule should seek to provide a reasonable person's estimation of what the parties would have done had they considered the matter ... ${ }^{125}$

Beatson leaves his counter-argument at that. Yet it allows for a much less didactic approach, investigating not only foreign and transnational rules on this point (as Goode does), but also the standard form contracts used and other indications of what businesspeople generally consider reasonable.

Such empirical investigation appears to have supported Llewellyn's decision

120. Blythe \& Co. v. Richards, Turpin \& Co., (1916) 85 K.B. 1425, 1427; see also In re An Arbitration Between Comptoir Commercial Anueersois \& Power, Son \& Co. (1920) 1 K.B. 868, 898 (Scrutton, L.J.) (stating that “[e]conomic profitableness is not "prevention")).

121. K.N. Llewellyn, On Warranty of Quality, and Society, 36 Colum. L. Rev. 699, 707 (1936).

122. Lauritzen A.S. v. Wijsmuller B.V. (The Super Servant Two), (1990) 1 Lloyd's Rep. 1 (U.K.).

123. In re Comptoir, 1 K.B. at 901-02; see also The Super Servant Two, 1 Lloyd's Rep. at 9.

124. Treitel, supra note 21 , at 449.

125. Jack Beatson, Increased Expense and Frustration, in Consensus Ad IDEM 121 (F D Rose ed., 1996). 
to allow for commercial impracticability and flexible allocation rules in the U. C.C. ${ }^{126}$ This was part of a longstanding and well articulated philosophy, framed by debates in contract law theory dating back to the 1920 s, which reinforce distinctly lower didactic formality in U.S. law. Of course, debates since the 1990s about reforming the U.C.C. have engendered empirical and theoretical studies that question the nature of expectations and practices in different trades and their optimal relationships to black-letter law. But they too have ingested heavy doses of legal realism. Similar comments apply to Japan. ${ }^{127}$

By contrast, despite statements by judges and academic commentators in England and New Zealand that contract law is to be shaped in accord with the expectations of commercial parties, there have been far fewer attempts to systematically and openly explore such expectations. Combined with more appeals to the need to promote certainty and careful planning of contractual relationships, this indicates that both jurisdictions put significantly more weight on didactic formality, reinforcing formal reasoning and related institutions more generally. Blackstone's words in 1809 still have more weight than in the United States and Japan: "Merchants ought to take their law from the courts, and not the courts from the merchants." 128

International sales and commercial contract law appear less prone to didactic formality. In his authoritative commentary on Article 79, one of the architects of CISG from the United States writes that:

Principles of efficiency and fairness can best be distilled from contracts prepared with the cooperation of both sellers and buyers; such cooperation can be achieved by a trade association ... The solutions provided by some of these contracts ... may be useful to parties who wish a more definite solution than can be provided by general rules of law; in addition, patterns that emerge from these contracts may provide guidance in applying the general rules of the Convention. ${ }^{129}$

126. White \& Summers, supra note 51.

127. See Nottage, Formal Requirements, supra note 6, Parts I and II. For a discussion of the long tradition of legal realism in U.S. contract law, see also Peer Zumbansen, The Law of Society: Governance Through Contract, 14 Ind. J. Global Legal Stud. 191 (2007).

128. Klaus Peter Berger, The New Law Merchant and the Global Market Place: A 21st Century View of Transnational Commercial Lazu, in The Practice of Transnational Law 1, 4 n. 15 (Klaus Peter Berger ed., 2001) (citing 1 Blackstone's Commentaries on the Laws of England 273 (15th ed. 1809)).

129. Honnold, supra note 84 at II 424 (emphasis added). 
The legislative history confirms that the drafters and delegates took such contract law in action as a guide to devising the key features for exemption from damages described earlier in this article.

Similarly, a leading German commentary has argued that the promisor's ability to control risks should be judged by reference to the contract itself and what the parties reasonably intended. However, suggesting a less formal approach, such ability to control risks is perceived as

only a (rebuttable) indication that by concluding the contract the promisor accepted responsibility for overcoming that risk. The particular circumstances under which a contract is concluded and its terms-both express and implied-can extend the promisor's guarantee [of performance] beyond the limits of Article 79 or restrict the extent to which Article 79 applies. ${ }^{130}$

By contrast, Anglo-New Zealand courts today tend to give more weight to express contract terms and interpret them more restrictively in order to refuse finding frustration. In effect, they thereby urge the parties to try ever harder to anticipate and to address future contingencies.

UPICC appears to go even further. As mentioned above, Article 6.2 adds provisions on economic hardship, which are found in a considerable proportion of crossborder contracts. However, it also clearly draws on doctrines from national laws allowing commercial impracticability (e.g., in Germany, Japan, and France for administrative contracts (imprévision)). It may also be going too far beyond current practice in adding these provisions even in an instrument that is primarily designed for, and applied in, situations where the parties chose to opt in, incor porating UPICC into their contract. As Berger points out, the Principles are a "pre-statement" of international contract law norms and practices, i.e., proposing a better solution, rather than always a "restatement." 31 UNIDROIT, an independent inter-governmental organization, also appears to have less transparency than UNCITRAL—subject to the requirements of the United Nations.

130. Peter Schlechtriem, Commentary on the UN Convention on the International Sale of Goods (CISG) art. 79, II 7 (1998).

131. Compare Berger, supra note 128 (referring to UPICC as a pre-statement of international commercial law), with Michael Joachim Bonell, An International Restatement of Contract Law: The UNIDROIT Principles of International Commercial Contracts (3d ed. 2005) (arguing that UPICC represent a restatement of international commercial law). 


\section{Conclusion}

Part II of this article demonstrated that English and New Zealand law have been much more wedded to formal reasoning along the dimension of authoritative formality compared to U.S. and Japanese law in the "time dimension," as well as the "contextual dimension," of contractual relationships. This disjunction is also found in other areas of contract law, reflecting and reinforcing differing orientations in the respective legal systems.

Part III moved beyond comparisons of legal reasoning to outline empirical studies of attitudes and practices relating to economic dislocation in contractual relations, especially in long-term contracts. A significant gap was identified between this contract law in action and the law in books, even in New Zealand. This occurs despite its comparatively high enforcement and truth formality, which generally close such gaps. However, adding the notion of didactic formality to Atiyah and Summers' framework reveals another important contrast between New Zealand and English law on the one hand (promoting the law in books), and Japanese and U.S. law on the other (more receptive to the law in action). Both CISG and UPICC fall somewhere between the two pairs at each end of this spectrum. UPICC may be more didactic than CISG, by adding hardship provisions, but the latter exhibit less authoritative formality.

Thus, even transnational law regimes are not necessarily fully convergent. Developing such regimes is made more difficult also by the form-substance dichotomy among domestic law systems on which they must partly draw. This adds to better-known tensions, such as differences still between the common law and civil law traditions, although developing Atiyah and Summers' framework usefully allows us to cut across that conventional dichotomy. ${ }^{132}$ In doing so, the framework also allows us to see significant aspects of Japanese contract law and practice as much less unique than many have tended to assert. That will be a more encouraging conclusion for advocates of more uniform contract law worldwide.

132. For a discussion of the civil law tradition, see John Henry Merryman et al., The Civil Law Tradition: Europe, Latin America, and East Asia (1994). 